\title{
Analysis on The Cultivation of College Students' Innovation and Enterprise Capability
}

\author{
Baiyi $A n^{1, a}$ and Wei Shen ${ }^{2, b^{*}}$ \\ ${ }^{1}$ College of Horticulture,Jilin Agricultural University,Jilin, China \\ ${ }^{2}$ College of Computer Science and Technology,Beihua University,Jilin, China \\ aswabyswaby@163.com, babyswabysw@163.com
}

Keywords: Universities; College students; Innovation ability; Entrepreneurial ability

\begin{abstract}
With the expansion of college enrollment, college graduates' employment is becoming increasingly severe. At present, in the innovation and entrepreneurship education of students in universities there still existsuch problems as the weak awareness and quality of university students' innovation, the older pattern ofentrepreneurship education, the community and school insufficient knowledge of innovation and entrepreneurship education, the curriculum system of innovation and entrepreneurship education still to be improved, and the extreme formalization of the practical base for the education. Innovation ability is conducive to improve students' social adaptability, professional knowledge and skills, and to enhance students' innovative spirit, so it is an important way to enhance the employability of students.
\end{abstract}

\section{Introduction}

With the increasing employment pressure of college students, the employment problem has been concerned by all sectors of society.In order to promote the self-confidence of college students, most of the colleges and universities strengthen their cultivation of students' innovation and entrepreneurship awareness and skills[1].This article will analyze the development of entrepreneurial education of colleges and the cultivation of innovative talents, and expounds respectively from the analysis on the current situation of university entrepreneurship[2] education and the effective measures to promote the cultivation of innovative talents in university entrepreneurship education[3].

\section{Analysis on the Current Situation of University Entrepreneurship Education}

At present, which made the innovation and entrepreneurship education of college students can only stay in the primary stage are the awareness of university students' innovation and entrepreneurship is generally weak in our country;the form of innovation entrepreneurship education is unitary;the mechanism of college students' sustainable development is not perfect; education mode has not been fully formed;the discipline system of innovation and entrepreneurship education is not perfect,,and failed to establish the win-win pattern of effective coordination of college students, schools and social,causing the university students' innovation and entrepreneurship consciousness and innovative character is weak[4].

The majority of college students' innovation and entrepreneurship education courses arranged disorderly, lack of coordination seriously and no unified system of innovation in entrepreneurship[5].On the one hand, the construction of practice base of college students innovation and entrepreneurship is uneven because of the differences on the understanding and emphysis of university students' innovation and entrepreneurship education[6].On the other hand, the practice base of college students' innovation is too formal,which becomes an important factor for constrainting the improvement of the students' innovation and entrepreneurship education quality,and it is due to the limitation of funding of innovation and entrepreneurship education for college students and relevant supporting policies and other factors[7]. 


\section{Effective Measures to Promote the Cultivation of Innovative Talents in University Entrepreneurship Education}

With the continuous deepening of China's education system, innovation and entrepreneurship education has been effectively developed."Creative talents" refers to the talents who have high research level, creative thinking and practical ability in a certain field."Entrepreneurial talent" refers to the talents who can change the technology innovation into a new product to meet the market demand and create a new enterprise.Innovative and entrepreneurial talents must have the ability of scientific and technological innovation and knowledge innovation,In order to cultivate more innovative talents, colleges and universities should take effective solutions, make full use of their own geographical and professional advantages and the level of teachers,so as to determine whether it can be consistent with their own entrepreneurial approach[8].Students choose a professional is not the same, then its own has some professional qualities as well as knowledge and skills are naturally different.Therefore, teachers in innovation and entrepreneurship education needs to combine educational content with student's professional, determine a proper training direction. This paper will carry out entrepreneurship education courses, construction of professional teaching staff, establish entrepreneurship education practice base, three parts to elaborate[9].

Carry out Entrepreneurship Education Curriculum. Colleges and universities to promote entrepreneurship education and innovative talents training,colleges and universities must carry out entrepreneurship education courses, and fully integrated into the innovative ideas,Innovation and entrepreneurship to build practical teaching system, the full development of innovation and entrepreneurship practice courses, allow students to practice while learning side, can promote effectively improve students' ability of innovation and entrepreneurship[10],to carry out a variety of innovative entrepreneurial practice.Traditional curriculum has some limitations, the main role of students seriously neglected in the study, especially after the new curriculum reform, the traditional curriculum has been unable to adapt to the actual situation of major institutions.Therefore, when an innovative curriculum must advance with the times, to abandon the traditional teaching philosophy, the use of new ideas to curriculum, teaching will focus on the students' practical ability, do not let the students learn to bear too much pressure, and strive to create a relaxed teaching environment.Some conducting educational activities are aimed at students in future endeavors can be effectively applied.Accordingly, we must join in the curriculum of some social practice, can invite some self-employed entrepreneurs to lecture, to deepen students' understanding of entrepreneurship, but also can tell the students about the hardships of entrepreneurship, to enable students to do business psychological preparation.Ractice makes perfect, this is the everlasting truth, especially for students, the only active to practice, in order to obtain a more flexible knowledge to enable students to society but also to carry out the ultimate goal of teaching.Accordingly, in the curriculum must be theoretical knowledge and practical teaching combined with the continuous reform of the education system, the combination of theory and practice of teaching has become the current trend, we only have to combine theory with practice in order to truly solve the current curriculum issues.

Construction of Professional Teaching Staff. The contingent of high quality teachers has a certain effect on the effective development of the innovation and entrepreneurship education,In order to promote the cultivation of innovative talents in university entrepreneurship education, the university must establish a strong contingent of teachers,cultivate the teachers' team which is suitable for the teaching practice and academic research of entrepreneurship education,the innovation and entrepreneurship education teachers should be composed of practical teachers and theoretical teachers, full-time teachers and part-time teachers.Colleges and universities should improve the level of teachers' professional quality, and enhance the good professional ethics,strengthen the professional sense of responsibility of the teachers, regular training for teachers, continue to strengthen the professional knowledge,the knowledge system is updated in a timely manner, to adapt to the characteristics of the development of the times,let the students learn the knowledge which has the actual meaning.University leaders can organize teachers to deepen the enterprise, to understand the 
situation of enterprise development,through the practice, teachers can refer to more vivid examples in the classroom teaching, make the teaching content and the society more fit.Teachers can use a variety of teaching methods to carry out teaching in the actual teaching process, to stimulate students' interest in learning, and improve their learning effect.

Establishing the Practice Base of Entrepreneurship Education. Entrepreneurship education practice base construction is the main task is to cultivate compound entrepreneurial talent,entrepreneurial ability is not a simple theory of teaching can be completed alone,entrepreneurship education practice base is a platform to cultivate students' ability to start a business for students. The school should strengthen cooperation with the outside enterprise when establishing the enterprise education practice base,organize students to participate in entrepreneurial activities, strengthen ties with the community.Teachers should also be involved in entrepreneurial activities, broaden their horizons, timely change ideas, master new technology, to achieve the effect of teaching benefits teachers as well as students.In order to promote the cultivation of innovative talents in university entrepreneurship education, the university must establish the practice base for the entrepreneurship education, and establish a variety of experimental centers on campus,on the other hand out of the school actively cooperate with the enterprise.Let college students entrepreneurial education into the school personnel training program, training college students to start their own typical.

\section{Conclusion}

Innovation is the core of the economy, the source of all development,and also the driving force of human progress[11].In order to promote the cultivation of innovative talents in university entrepreneurship education, the students have a deeper understanding of entrepreneurship education courses, we must strengthen the innovation and reform of entrepreneurship education curriculum,conform to the trend of the times, to cultivate more innovative talents for our country[12].Universities should focus on entrepreneurship research and teaching,open a business or entrepreneurship research,set up a special enterprise education center and Research Institute, to cultivate students' innovative spirit and practical ability,cultivate more innovative talents for our country,and promote the comprehensive development of China's education field.

\section{Acknowledgement}

The authors wish to thank the Education Department of Jilin Province [2015](127th) and [2015](182nd),Jilin science and Technology Bureau(201467006),Science and Technology Department of Jilin Province (20150204045NY), Jilin Province Education Science Planning Project

(GH14126) 、 (GH14127) under which the present work was possible.

\section{References}

[1] Lucia Naldi,Mattisa Nordqvist.Entrepreneurial Orientation,Risk Taking,and performance in Family Firms[J].Journal of the family firm institute,2007(1):33-47.

[2] Emest L Boyer. Schlarship Reconsidered: Priorities of the Professoriate. Princeton: The Camegie Foundation for the Advancement of Teaching, 1990.

[3] Wallmark J T, McQueen D H, Sedig K Q. Measurement of output from university research, a case study[J]. Engineering Management, IEEE Transactions, 2008, 3:175-180.

[4] Youtie J , Shapira P. Building an innovation hub: a case study of the transformation of university roles in regional technological and economic development[J]. Research Policy, 2008, 37(8): 1188-1204. 
[5] Geenhuizen M V, Soetanto D P. Academic spin-offs at different ages: A case study in search of key obstacles to growth[J]. Technovation, 2009, 29(10):671-681.

[6] Fini R, Grimaldi R, Santoni S, et al. Complements or substitutes? The role of universities and local context in supporting the creation of academic spin-offs[J].Research Policy, 2011, 40(8): 1113-1127.

[7] Information on http://www.people.com.cn/GB/32306/33232/14743200.html

[8] Information on http://www.ox.ac.uk/about/oxford - people/famous - oxonians

[9] Anders Lundstrom,Lois Stevenson. Entrepreneurship Policy:Theory and practice[M].New Mexico,Springer,2005.

[10] Anders Hoffinann,Hesham M. Gabr. A General Policy Framework for Entrepreneurship[M].Dahlerups Pakhus:FORA,2006,

[11] Anders Lundstrom, Lois Stevenson. Entrepreneurship Policy:Theory and Practice[M].Springer, 2010.

[12] Nabi G, et al. From student to entrepreneur: Towards a model of graduate entrepreneurial career-making[J].Journal of Education and Work, 2010,23(5):389-411. 